\title{
Analisis Pemanfaatan Dana Zakat, Infak, Sedekah dan Wakaf dengan Model Fungsi Actuating
}

\author{
Ferri Alfadri' ${ }^{1}$, Darwis Harahap ${ }^{2}$, Alwijah Indah Syafitri ${ }^{3}$ \\ 1,2,3 Institut Agama Islam Negeri Padangsidimpuan \\ 1,2,3 Jl. H.T. Rizal Nurdin Km 4,5 Sihitang Kota Padangsidimpuan \\ E-mail: feri@iain-padangsidimpuan.ac.id ${ }^{1}$, darwisharahap@iain-padangsidimpuan.ac.id ${ }^{2}$, \\ alwijahlubis20@gmail.com³
}

\begin{abstract}
ABSTRAK
Pengelolaan zakat dilakukan dengan sistem kerja dan profesional serta pengelolaan dan pengelolaan perusahaan. Namun, aturan atau peraturan yang sesuai dengan hukum syariah tidak boleh ditinggalkan. Mengingat pentingnya hal tersebut, penelitian ini berfokus pada Analisis Pemanfaatan Dana Ziswaf dengan Model Fungsi Aktuasi di Kota Padangsidimpuan. Jenis penelitian ini adalah penelitian kualitatif, pendekatan yang digunakan dalam penelitian ini adalah pendekatan manajemen. Metode pengumpulan data menggunakan beberapa instrumen yaitu: observasi, dokumentasi, dan wawancara. Analisis data menggunakan analisis interaktif dengan tiga langkah yaitu reduksi data, penyajian data, dan penarikan kesimpulan. BAZNAS Kota Padangsidimpuan telah menunjukkan keberhasilan dalam mengelola dana ZISWAF yaitu penyaluran dan penyaluran yang tepat dan tepat sasaran, meskipun pengentasan kemiskinan belum terlaksana secara signifikan, ZISWAF di Kota Padangsidimpuan telah membantu kehidupan penerima manfaat melalui bantuan konsumtif dan produktif .
\end{abstract}

\section{Kata Kunci: Actuating, Manajemen, Pengelolaan Zakat, Wakaf}

\begin{abstract}
The management of zakat is carried out with a work and professional system as well as company management and management. However, rules or regulations in accordance with sharia law should not be abandoned. Given the importance of this, this study focuses on the Analysis of Ziswaf Fund Utilization with the Actuating Function Model in the City of Padangsidimpuan. This type of research is qualitative research, the approach used in this research is the management approach. The data collection method uses several instruments, namely: observation, documentation, and interviews. Data analysis used interactive analysis with three steps, namely data reduction, presenting data and drawing conclusions. BAZNAS at Padangsidimpuan city has shown success in managing ZISWAF funds, namely the distribution and distribution of the right and right target, although poverty alleviation has not been implemented significantly, ZISWAF in the city of Padangsidimpuan has helped the beneficiaries' lives through consumptive and productive assistance.
\end{abstract}

Keywords: Actuating, Management, Utilizing, Waqf, Zakat 


\section{2 | Analisis Pemanfaatan Dana Zakat, Infak, Sedekah dan Wakaf dengan Model Fungsi Actuating}

\section{PENDAHULUAN}

Di Indonesia penghimpunan zakat bersifat sukarela, artinya sebagai disebutkan sebelumnya, hal ini bergantung pada kesadaran individu akan kewajibannya sebagai muslim. Kemudian, zakat dikumpulkan oleh pemerintah dan non-pemerintah (swasta), tetapi (Fahlefi, Hasan and Alimin, 2019) menyatakan bahwa lembaga nonpemerintah di Indonesia cukup fleksibel untuk menjalankan program. Pengelolaan penghimpunan zakat dan pendistribusiannya bisa diperkuat juga oleh menggunakan financial technology), namun tidak semua lembaga zakat dapat menerapkan hal tersebut teknologi. Ketersediaan sumber daya manusia yang berkualitas menjadi faktor utama untuk mampu untuk merealisasikannya. Sumber daya manusia yang berkualitas tidak hanya dapat meningkatkan penghimpunan zakat dan pendistribusiannya tetapi juga pengelolaan zakat secara umum.

Pemanfaatan dana Zakat, Infaq, Shodaqoh dan Wakaf (ZISWAF) adalah salah satu cara untuk maksimalisasi pemanfaatan dana ZISWAF untuk mensejahterakan masyarakat. Sesuai dengan "Undang-Undang Republik Indonesia" tentang Pengelolaan Zakat tanggal 23 Tahun 2011. Peraturan tersebut menetapkan bahwa pengelolaan Zakat bertujuan untuk meningkatkan efisiensi layanan masyarakat Zakat, dan untuk meningkatkan kepentingan Zakat dalam upaya mengurangi angka kemiskinan dan meningkatkan kesejahteraan masyarakat.

Seperti yang tertera pada laporan keuangan Badan Amil Zakat Nasional (BAZNAS) per-Desember di tahun 2020 jumlah total penerimaan dana yakni sebesar \pm Rp 386 miliar dan total keseluruhan penyaluran nya sebanyak \pm Rp. 251 Miliar (Pid.BAZNAS.go.id: 2020). Ditinjau dari besarnya potensi tersebut, sangat merugi jika pemanfaatan tidak terdistribusi secara merata. Terlebih lagi permasalahan kesejahteraan masyarakat di Kota Padangsidimpuan yang masih membutuhkan bantuan secara materi.

Sangat perlu untuk menggunakan pemanfaatan ini, disebabkan dengan adanya sistem pemanfaatan ZISWAF yang tepat mampu menjangkau pengguna (penerima manfaat) yang membutuhkannya. Mustahiq merupakan obyek guna, dan manfaatnya sejalan dengan maksud dan tujuan. Sasarannya adalah orang-orang yang kurang beruntung (kelompok ashnaf). Orang yang kurang mampu dalam Islam disebut kelompok ashnaf. Q.S At-Taubah ayat 60 disebutkan bahwa ada delapan (8) kelompok ashnaf, yaitu, amil, fakir miskin mualaf, riqab, gharim, fi sabilillah dan ibnu sabil. Ayat ini menunjukkan bahwa kepemilikan dana ZISWAF berlaku untuk semua kelompok, dan semua kelompok yang ber-hak sama. Berdasarkan hal ini, pengelola dana ZISWAF tidak dapat mengalokasikan dana kepada pihak selain Mustahiq.

Untuk menggunakan dana ZISWAF secara efektif dan menentukan orang yang tepat untuk membangun sistem dan mampu memanajemen. Fungsi manajemen antara lain meliputi POAC (Planning, organizing, actuating, dan controlling). Berkaitan dengan hal tersebut, dalam pembahasan penelitian ini realisasi fungsi eksekutif sangat diperlukan, karena 
fungsi eksekutif merupakan fungsi yang berhubungan langsung dengan pelaksanaan (Shaleh: 1977). Tanpa adanya pergerakan, proses pemanfaatan tidak berjalan sesuai rencana yang menjadi dasar pentingnya pelaksanaan fungsi eksekutif dalam proses pengelolaan. (Ez and Maisyal, 2020).

Pemanfaatan dana ZISWAF di sini dapat memberikan solusi bagi pemerintah untuk mengentaskan kemiskinan warga Padangsidimpuan seperti hal-nya yang di kemukakan oleh (Haryanti, Adicahya and Ningrum, no date). Untuk memanfaatkan dengan benar dan menggunakan dana ZISWAF penerima dengan benar, sangat dibutuhkan manajemen yang efisien, baik dan benar. Mengenai pelaksanaan yang akan dilaksanakan, penulis memfokuskan penerapan fungsi khusus pada pemanfaatan dana ZISWAF, karena hal ini akan memudahkan penyaluran ke berbagai daerah yang sangat memerlukan bantuan, dan pelaksanaannya akan lebih difokuskan pada pencapaian kebenaran. Berdasarkan latar belakang yang tertera diatas, penulis fokus melakukan penelitian dengan judul "Analisis Pemanfaatan Dana Ziswaf Dengan Model Fungsi Actuating"

\section{KAJIAN TEORITIS}

\section{Model Fungsi Actuating (Penggerakan)}

Model adalah tindakan yang diambil oleh individu, pejabat, pemerintah atau kelompok swasta untuk mencapai tujuan yang diuraikan dalam keputusan kebijakan (Abdul: 2008). Model tersebut juga dapat dikatakan bahwa pemanfaatan bukan hanya suatu kegiatan, tetapi juga suatu kegiatan yang dirumuskan dan dilaksanakan secara cermat sesuai dengan acuan normatif tertentu untuk mencapai tujuan kegiatan (Hakim, 2016).

Menurut manajemen adalah ilmu dan seni yang mengatur proses penggunaan sumber daya manusia dan sumber daya lain secara efektif dan efisien untuk mencapai tujuan tertentu. (Zanah, 2016) Menurut pemahaman George R. Terry tentang manajemen, manajemen memiliki empat fungsi, yaitu; Planning (perencanaan), Merumuskan dan merencanakan kegiatan yang diperlukan untuk mencapai tujuan individu / kelompok yang diinginkan, dapat juga berupa visi dan misi (Maduretno and Fajri, 2019), Organizing (pengorganisasian), adalah penetapan penentuan masing masing job desk dan membuat ketentuan dalam sinergitas yang diperlukan (Dakhi, 2016), Actuating (penggerakan), adalah usaha untuk menggerakkan masing - masing anggota kelompok sesuai job desk dalam melaksanakan pekerjaan, dan Controlling (pengawasan), adalah kegiatan untuk melakukan pengawasan yang disesuaikan antara proses pelaksanaan dengan rencana yang telah ditentukan (Hasibuan: 2010).

Dalam artian umum, actuating adalah suatu cara untuk dapat menggerakkan orang lain untuk mencapai suatu tujuan. Menurut (Shaleh: 1977), penggerakan yang diaksud yaitu 
suatu bentuk usaha seorang manajer dalam menggerakan masing - masing individu ataupun kelompok untuk dapat melakukan suatu pekerjaan secara maksimal berdasarkan planing dan organizing yang sudaht ditentukan, dapat berupa; pemberian motivasi, menjalin hubungan, menjalin komunikasi yang baik, dan melakukan pengembangan atau peningkatan kegiatan (Setiyowati, 2017).

Tujuan Actuating adalah upaya atau tindakan yang dilakukan oleh seorang pemimpin untuk meningkatkan minat dan upaya untuk lebih memahamkan posisinya sehingga secara sadar dapat menjalankan tugasnya sesuai dengan rencana yang telah ditetapkan sebelumnya. Contoh perilaku Actuating antara lain memberikan dorongan atau motivasi, memberikan bimbingan melalui perilaku atau tindakan yang patut dicontoh, dan memberikan bimbingan melalui bimbingan yang benar, jelas dan tegas. (Andri dan Endang: 2015).

\section{Pemanfaatan Dana Zakat Infaq Shodaqoh dan Wakaf (ZISWAF)}

Pemanfaatan adalah segala upaya yang dilakukan untuk memenuhi kebutuhan hidup, dan tujuannya untuk meningkatkan kesejahteraan masyarakat dengan meningkatkan taraf hidup (ekonomi) yang kurang beruntung (Setiyowati, 2017). Tingkat pemanfaatan sangat erat kaitannya dengan pengembangan masyarakat. Dengan memanfaatkannya maka pembangunan masyarakat dapat meningkat dan berdampak baik pada perubahan sosial di masyarakat, perubahan sosial tersebut telah menjadi tujuan dakwah dan upaya untuk memajukan dunia dan kesejahteraan masyarakat di masa yang akan datang (Ali Aziz: 2005). Zakat adalah bahasa dari kata "zakkaan", yang berarti kesuburan, kesucian, berkah dan keramahan. Zakat juga memiliki arti lain yaitu al-barakah (berkah), an-nama (tumbuh kembang) dan at-thaharah (suci) (Wahyuddin: 2006).

Infaq menurut bahasa berasal dari kata "infaaqan" yang berarti mengeluarkan sesuatu (harta). Sedangkan infaq menurut pasal 1 Undang-Undang RI No 23 Tahun 2011 Tentang Pengelolaan Zakat adalah harta yang dikeluarkan oleh seseorang atau badan usaha untuk kemaslahatan umum

Shodaqoh menurut bahasa bersal dari kata "shadaqa" yang berarti benar. Menurut (Al-Qardhawi: 1991) bahwa shodaqoh itu berarti bukti kebenaran iman dan membenarkan adanya hari kiamat. Sedangkan menurut pasal 1 Undang-Undang RI No 23 Tahun 2011 Tentang pengelolaan Zakat, shodaqoh adalah harta atau nonharta yang dikeluarkan oleh seseorang atau badan usaha di luar zakat untuk kemaslahatan umum.

Wakaf secara bahasa berasal dari kata waqafa-yaqifu yang artinya berhenti. Perkataan wakaf juga dikenal dalam istilah ilmu tajwid yang bermakna menghentikan bacaan, baik seterusnya maupun untuk mengambil nafas sementara. Bahkan wakaf dengan makna berdiam ditempat juga dikaitkan dengan wukuf, yakni berdiam di Arafah pada tanggal 9 Dzulhijjah ketika menunaikan ibadahh Haji . Menurut UU RI No. 41 Tahun 2004 Tentang Wakaf, istilah wakaf merupakan perbuatan hukum waqif (orang yang memberi JISFIM: Journal of Islamic Social Finance Management, Volume 1, No 1 Tahun 2021 http://jurnal.iain-padangsidimpuan.ac.id/index.php/JISFIM 
wakaf) untuk memisahkan dan/atau menyerahkan sebagian harta benda miliknya untuk dimanfaatkan selamanya atau untuk jangka waktu tertentu sesuai dengan kepentingannya guna keperluan ibadah dan/atau kesejahteraan umum menurut syariah (Ramayulis: 2010).

\section{Badan Amil Zakat Nasional (BAZNAS)}

Badan Amil Zakat Nasional (BAZNAS) merupakan badan resmi dan satu-satunya yang dibentuk oleh pemerintah berdasarkan Keputusan Presiden RI No. 8 Tahun 2001 yang memiliki tugas dan fungsi menghimpun dan menyalurkan zakat, infaq, dan sedekah (ZIS) pada tingkat nasional ('uu_41_o4.pdf', no date). Lahirnya Undang-Undang Nomor 23 Tahun 2011 tentang Pengelolaan Zakat semakin mengukuhkan peran BAZNAS sebagai lembaga yang berwenang melakukan pengelolaan zakat secara nasional. Dalam UU tersebut, BAZNAS dinyatakan sebagai lembaga pemerintah nonstruktural yang bersifat mandiri dan bertanggung jawab kepada Presiden melalui Menteri Agama. Dengan demikian, BAZNAS bersama Pemerintah bertanggung jawab untuk mengawal pengelolaan zakat yang berasaskan: syariat Islam, amanah, kemanfaatan, keadilan, kepastian hukum, terintegrasi dan akuntabilitas (Deni, 2018).

Adapun kegiatan yang digerakkan dalam proses penyaluran zakat di BAZNAS yaitu diawali dengan menginput data calon mustahik masing-masing daerah. BAZNAS menanyakan itu Setiap UPZ membuat daftar nama calon mustahiq di wilayahnya. BAZNAS juga menginput data calon mustahiq berdasarkan proposal yang diajukan secara individu / kolektif ata berdasarkan laporan masyarakat tentang kondisi darurat. BAZNAS melakukan rekapitulasi data calon mustahiq kemudian dikelompokkan menurut pemekaran wilayah yang akan disurvei. Bagaimanapun, BAZNAS mensurvei kondisi riil calon mustahiq dan verifikasi hasil survey. Survei dilakukan oleh petugas lapangan untuk mendapatkan informasi yang lengkap tentang yang sebenarnya kondisi calon mustahiq, dan untuk memastikan apakah calon tersebut mustahik benar-benar berhak menerima zakat sesuai dengan yang ditetapkan kondisi dan kriteria (Fahlefi, Hasan and Alimin, 2019).

\section{METODOLOGI}

Jenis Penelitian ini adalah penelitian kualitatif deskriptif. Penelitian ini memuat berbagai uraian-uraian yang berbentuk tulisan tentang model fungsi actuating (penggerakan) dalam pemanfaatan dana zakat, infaq, shodaqoh dan wakaf (ZISWAF) di Badan Amil Zakat Nasional (BAZNAS) Kota Padangsidimpuan.

Sumber data penelitian adalah data primer berupa dokumen resmi mengenai mengenai pelaksanaan Pemanfaatan Dana ZISWAF Dengan Model Fungsi Actuating serta hasil wawancara dari pengelola BAZNAS, donatur serta para penerima manfaat di kawasan Kota Padangsidimpuan. Pengumpulan data pada penelitian ini penulis menggunakan teknik Interview, observasi serta dokumentasi. 


\section{HASIL PENELITIAN}

\section{Analisis Pemanfaatan Dana Ziswaf Dengan Model Fungsi Actuating}

Untuk mencapai tujuan mencapai manajemen yang efektif, maka fungsi actuating sangat penting harus dimaksimalkan dikarenakan prose iniliah yang menjadi poros penggerak yang berhubungan langsung dengan proses pelaksanaan manajemen. Oleh sebab tersebutlah dapat ditarik kesimpulan bahwa dengan fungsi actuating ini lah, fungsi manajemen lainnya dapat berjalan secara baik dan efektif (Shaleh: 1977).

Peneliti menggunakan teori yang dikemukakan oleh (Shaleh: 1977) untuk analisis, yaitu memberikan motivasi, memberikan bimbingan, membangun hubungan, menjaga mengembangkan komunikasi interaktif serta meningkatkan proses pelaksanaan. Melalui informasi data yang didapatkan penulis, kemudian penulis membandingkannya dengan teori actuating sebagaimana idealnya teori yang disebutkan di atas, dan hasil nya diperoleh data yang saling keterkaitan antara teori dan realisasi aktual di BAZNAS Kota Padangsidimpuan diantaranya adalah sebagai berikut yaitu pemberian motivasi dan pembimbingan/pembinaan, menjalin hubungan, komunikasi dan pengembangan atau peningkatan pelaksanaan.

\section{Pemberian Motivasi}

Berdasrkan hasil interview dengan penanggung jawab bidang pemberdayaan BAZNAS kota Padangsidimpuan mengemukakan, bahwa pemberian motivasi sangat penting dilakukan dikarenakan hal tersebut adalah suatu bentuk upaya mendorong semangat para Mustahiq. Untuk menggugah semangat masyarakat, upaya BAZNAS Kota Padangsidimpuan akan melakukan pembinaan yang efektif. Dari hasil semangat pembinaan ini lah diharapkan dapat meningkatkan pemahaman Mustahiq.

\section{Pembimbingan/ Pembinaan}

Berdasarkan informasi yang didapat penulis bahwa, adanya kesesuaian implementasi yang terjadi antara teori dan fakta yang ditemukan penulis di lapangan. Tujuan dari pembina BAZNAS Kota Padangsidimpuan kepada para mustahiq diantaranya adalah untuk membantu mengatasi kesulitan ekonomi yang dialami mustahiq seperti terbatasnya keuangan, kesehatan fisik dan juga pengetahuan, sehingga diarapkan para mustahiq mampu memperbaiki kondisi kehidupannya menjadi lebih baik lagi.

BAZNAS Kota Padangsidimpuan terus berupaya untuk berinovasi mengembangkan konsep yang lebih produktif lagi untuk membantu para mustahiq agar mampu mengalokasikan dana yang diterima bukan hanya untuk kebutuhan konsumtif tetapi juga bisa di dayagunakan untuk keperluan yang bersifat produktif dan mampu menghasilkan guna mengubah kondisi kelangsungan hidup jangka panjang yang lebih maju.

\section{Menjalin Hubungan}

Salah satu prinsip yang diterapkan BAZNAS Kota Padangsidimpuan kepada para JISFIM: Journal of Islamic Social Finance Management, Volume 1, No 1 Tahun 2021 http://jurnal.iain-padangsidimpuan.ac.id/index.php/JISFIM 
mustahiq-nya berupa prinsip kekeluargaan. Prinsip ini diharapkan dapat membangun dan menjaga silaturrahim antara BAZNAS Kota Padangsidimpuan dengan para mustahiq.

\section{Komunikasi}

Berdasarkan hasil wawancara, metode komunikasi yang dilakukan oleh BAZNAS Kota Padangsidimpuan untuk selalu menjaga komunikasi yang efektif dengan para mustahiq, yaitu mendatangi rumah mustahiq, memberikan informasi via SMS dan Whatsapp (Media Sosial), dan pembinaan atau pendampingan

Hal ini diharapakan BAZNAS Kota Padangsidimpuan dapat menjadi upaya untuk meminimalisir jarak yang tercipta antar mustahiq dan BAZNAS Kota Padangsidimpuan serta, hal ini juga merupakan upaya untuk memberikan sumber informasi terkini yang mudah dan cepat untuk diakses seputaran nformasi dan pengembangan atau peningkatan inovasi dan kreatifitas dalam menggunakan dana yang telah diterima

\section{Pengembangan atau peningkatan pelaksanaan}

Dalam rangka mempertahankan dayaguna keberadaan BAZNAS Kota Padangsidimpuan di masyarakat umum, BAZNAS Kota Padangsidimpuan terus berusaha mengembangkan dan menyempurnakan rencana yang lebih inovatif menyesuaikan terhadap budaya yang berlaku di Kota Padangsidimpuan. Adapun pengembangan yang dimaksud tersebut seperti : adanya kesadaran, kemampuan, pengetahuan dan keterampilan profesional, yang diharapkan dapat lebih ditingkatkan dan dikembangkan (Shaleh, 1977). BAZNAS Kota Padangsidimpuan menerapkan metode ini melalui proses pembelajaran dan pengajaran. Salah satu kegiatan yang dilakukan BAZNAS Kota Padangsidimpuan seperti diadakannya Event- event dan juga seminar umum untuk membantu mensosialisasikan program-program bantuan yang akan di distribusikan.

\section{Analisis Hasil dari Model Fungsi Actuating Dalam Pemanfaatan Dana ZISWAF di BAZNAS Kota Padangsidimpuan.}

Terkait pemanfaatan zakat, hal ini perlu fokus untuk mempertimbangkan target distribusi zakat di berbagai sektor kehidupan, termasuk antara lain (Iqbal, Rusli and Musyahidah, 2019); Sektor ekonomi, seperti masyarakat pendapatan relatif rendah karena kurangnya modal ventura, kurang kemampuan dalam bidang budidaya pertanian dan lemah kinerja di bidang agribisnis; Sektor agama itu termasuk agama lembaga pendidikan dan masyarakat yang berkaitan dengan agama seperti orang yang tidak mampu membayar hutang, imam masjid, penceramah, madrasah guru, petugas syara, dan lain-lain yang menerima lebih sedikit perhatian dari masyarakat; Mengoptimalisasi kinerja pengelolaan dana sangatlah tergantung pada distribusi pemanfaatan dana itu sendiri. Berdasarkan hasil informasi yang didapatkan yang menjadi masalah utama yaitu pendistribusian dana agar digunakan secara efektif (Akbar', 2020). Hal tersebut dikarenakan, dengan adanya pendistribusian yang efektif diharapkan dapat mengoptimalisasi manfaat yang diterima dan menjadi solusi yang baik 
untuk masalah kemiskinan.

Pimpinan BAZNAS Kota Padangsidimpuan Drs. Ali Musa Siregar menyatakan beberapa indikator penentu keberhasilan pengembangan sistem pengelolaan ZISWAF oleh BAZNAS Kota Padangsidimpuan, yaitu sebagai berikut:

\section{Kepatuhan hukum BAZNAS kota Padangsidimpuan.}

Seluruh Lembaga zakat baik organisasi ataupun individu yang melakukan kinerja mulai dari mengumpulkan sampai mendistribusikan dana ZISWAF wajib memiliki legalitas, dikarenakan hal tersebut tercantum pada peraturan perundang-undangan BAZNAS Nomor 3 Tahun 2014 tentang Organisasi dan Tata kinerja badan amil zakat nasional Provinsi dan Kabupaten/Kota. Memiliki legalitas hukum juga bisa membuktikan bahwa BAZNAS Kota Padangsidimpuan merupakan lembaga yang profesional dan bertanggungjawab. Berdasarkan hasil informasi yang diperoleh BAZNAS Kota Padangsidimpuan adalah lembaga ZISWAF yang paling utama di kota Padangsidimpuan dan paling banyak dikenal dikarenakan amanah dan terpercaya dalam kinerja kepengelolaan dana ZISWAF menurut masyarakat.

\section{Peningkatan dana ZISWAF dan distribusi yang efisien kepada mustahiq.}

Secara keseluruhan BAZNAS Kota Padangsidimpuan mengalami peningkatan donasi yang diterima merupakan hasil dari kinerja BAZNAS Kota Padnagsidimpuan. Sehingga menyebabkan semakin besar pula dana yang di distribusikan. Hal tersebut dikrenakan menurut masyarakat bahwa BAZNAS Kota Padangsidimpuan yang mampu menjaga amanah dari donatur dalam pengelolaan dana ZISWAF. Hal tersebut akan mempengaruhi para donatur dikarenakan, adanya anggapan bahwa dana yang sudah didonasikan kepada BAZNAS Kota Padangsidimpuan dapat dipercaya. Oleh karena itu para donatur tidak merasa ragu lagi untuk berdonasi untuk selanjutnya.

\section{Peningkatan hasil pengentasan kemiskinan.}

Indonesia merupakan negara yang memiliki potensi penduduk (sumber daya manusia) yang besar yang berguna untuk mendukung pencapaian tujuan pembangunan nasional dan daerah pertumbuhan ekonomi. Salah satu tujuan utama pembangunan ekonomi adalah pengurangan jumlah orang miskin (Sulistya, Budirahayu and Ningtyas, 2020).

Menurut Drs. Ali Musa Siregar yang menjadi hambatan bagi BAZNAS Kota Padangsidimpuan, adalah pertama, mustahiq kurang aktif pada kegiatan pembinaan berkelanjutan. Berdasrkan hasil penenlitian ada beberapa indikator penyebab mustahiq kurang aktif adalah kurangnya rasa percaya diri, problema keluarga, adanya keraguan untuk berinovasi, kurangnya menjalin komunikasi yang baik.

Kedua, mustahiq lebih memilih berprilaku konsumtif setelah mendapat bantuan dari pada berprilaku produktif. Adapun yang dikategorikan konsumtif yang dimaksud adalah bantuan berupa uang tunai langsung. Berlandaskan hal inilah, BAZNAS Kota Padangsidimpuan membuat tindakan seperti pembinaan yang bertujuan pemanfaatan dana 
yang lebih produktif, dan pemerataan distribusi yang baik dan adil. hal tersebut diharapkan mampu menyadarkan para mustahiq agar segera meningkatkan kualitas hidupnya.

\section{Penguatan kemitraan antara stake holder}

Berdasarkan hasil penelitian, dikarenakan adanya beberapa instansi yang ingin menjalin mitra dengan BAZNAS Kota Padangsidimpuan, penulis menyimpulkan bahwa banyaknya lembaga atau istansi yang menilai BAZNAS Kota Padangsidimpuan bersifat amanah dan dapat dijadikan mitra yang baik. Oleh karena itu, pemanfaatan dana ZISWAF mampu diharapkan berkembang secara optimal. Salah satu indikator penilaian keberhasilan lembaga dalam pemanfaatan dana ZISWAF tidak terlepas dari

Berdasarkan hasil wawancara dengan beberapa donatur di Kota Padangsidimpuan menyampaikan, BAZNAS Kota Padangsidimpuan telah memperlihatkan tingkat keberhasilan dalam pemanfaatan dana ZISWAF, seperti penyaluran yang cukup efisien dalam artian tepat guna dan sasaran bagi para mustahiq yang penerima manfaat, pengentasan tingkat kemiskinan belum terwujud secara menyeluruh kepada para mustahiq, namun BAZNAS Kota Padangsidimpuan sudah menunjukkan manfaat melalui adanya peningkatan pemenuhan kehidupan bagi para mustahiq melalui bantuan secara konsumtif ataupun produktif (Interview: Andrija dan Yusuf)

\section{KESIMPULAN}

Pemanfaatan dana ZISWAF dengan fungsi actuating di BAZNAS Kota Padangsidimpuan, berupa memberikan motivasi kepada para mustahiq, melaku pembimbingan dan pendampingan, menjalin hubungan yang baik, menjaga komunikasi dengan baik, kemudian melakukan pengembangan atau peningkatan program. Berdasarkan hasil penelitian, hal ini berpengaruh secara signifikan kepada para mustahiq, para mustahiq menyatakan bahwa, dengan adanya program dan manjemen kelola pemanfaatan dana ini mereka merasa sangat terbantu oleh BAZNAS Kota Padangsidimpuan. Hasil dari fungsi actuating dalam pemanfaatan dana zakat, infaq, shodaqoh dan wakaf (ZISWAF) di BAZNAS Kota Padangsidimpuan, yaitu untuk mengetahui faktor-faktor tolak ukur penentu keberhasilan dalam memanfaatkan dana dan pengembangan zakat oleh BAZNAS Kota Padangsidimpuan, yaitu kepatuhan hukum BAZNAS kota Padangsidimpuan, peningkatan dana ZISWAF dan distribusi yang efisien kepadamustahiq, peningkatan hasilpengentasan kemiskinan, penguatan kemitraan antarastake holder. BAZNAS Kota Padangsidimpuan telah menunjukkan suatu keberhasilan dalam memanfaatkan dana ZISWAF untuk dikelola, berupa penyaluran dan pendistribusian yang efisien, BAZNAS Kota Padangsidimpuan juga berhasil membantu pengentasan bagi para mustahiq, dan juga BAZNAS Kota Padangsidimpuan sudah dapat membantu kelayakan hidup bagi para mustahiq melalui bantuan konsumtif maupun produktif yang di distribusikan. 


\section{Fungsi Actuating}

\section{DAFTAR PUSTAKA}

Abdul, Wahab Sholichin. (2008), Analisis Kebijakan dari Formulasi ke Implementasi Kebijakan Negara. Jakarta: Bumi Aksara

Ali Aziz, Moh, Rr. Suhartini dan A. Halim, (2005) Dakwah Pemberdayaan Masyarakat Paradigma Aksi Metodologi. Yogyakarta: PT LKis Pelangi Aksara

Ali, Muhammad Daud, (1988) Sistem Ekonomi Islam Zakat dan Wakaf. Jakarta: UI Press.

Al-Qardhawi, Yusuf. (1991), Hukum Zakat. Jakarta: Litera Antar Nusa.

Baznas - Badan Amil Zakat Nasional. Available at: https://baznas.go.id/ (Accessed: 19 May 2021).

Dakhi, Y. (2016) Jurnal Warta, Implementasi Poac Terhadap Kegiatan Organisasi Dalam Mencapai Tujuan Tertentu, Edisi : 50.

Deni, dkk, (2018), JEBI (Jurnal Ekonomi dan Bisnis Islam), Mengukur Kinerja Pengelolaan Zakat Di Badan Amil Zakat Nasional (BAZNAS) Vol 3, No 1,

Departemen Pendidikan dan Kebudayaan, (2005), Kamus Besar Bahasa Indonesia. Jakarta: Balai Pustaka

Dimyati, (2017), Al- Tijary, Urgensi Zakat Produktif Indonesia, Vol. 2, No. 2

Ez, I. and Maisyal, N. (2020) 'Pendayagunaan Zakat Untuk Penanggulangan Pandemi Covid-19 Perpektif Filsafat Hukum Islam', Al - Muamalat: Jurnal Hukum dan Ekonomi Syariah, 5(1), pp. 1-26. doi: 10.32505/muamalat.v5i1.1849.

Fahlefi, R., Hasan, A. and Alimin, A. (2019) 'Management Model Of Zakat Collection And Its Distribution For Zakat Agency', Business and Politics, p. 12

Hakim, A. (2016), Pengelolaan Zakat Pertanian Di Lazis Nu Kabupaten Kendal, Wahana Akademika: Jurnal Studi Islam dan Sosial, Vol. 2, No. 2

Haryanti, N., Adicahya, Y. and Ningrum, R. Z, (2020), IQTISADIYA: Jurnal Ilmu Ekonomi Islam ,Peran Baznas Dalam Meningkatkan Perekonomian Masyarakat, p. 10. Vol. VII No. 14

Hasibuan, Malayu S,P. (2010), Organisasi dan Motivasi. Jakarta: PT. Bumi Aksara

Iqbal, M., Rusli, R. and Musyahidah, M. (2019) 'Management Strategies of Professional Zakat Funds for Mustahiq Family Welfare By Amil Zakat Body', International Journal Of Contemporary Islamic Law And Society, 1(1),doi: 10.24239/ijcils.Vol1.Iss1.4

Irfandi, (2020), Pemanfaatan Zakat Untuk Penanggulangan Pandemi COVID-19, AlJISFIM: Journal of Islamic Social Finance Management, Volume 1, No 1 Tahun 2021 http://jurnal.iain-padangsidimpuan.ac.id/index.php/JISFIM 
Muamalat : Vol. 5, No. 1, Ed. 1

Khusaeri, (2015), AL-A’RAF, Wakaf Produktif, Vol. XII, No. 1

Malayu S.P Hasibuan. (2010), Manajemen Sumber Daya Manusia. Jakarta: Bumi Aksara.

Maduretno, T. W. and Fajri, L. (2019) 'The effect of optimization learning resource based on Planning, Organizing, Actuating, Controlling (POAC) on contextual learning to students' conceptual understanding of motion and force material', Journal of Physics: Conference Series, 1171, p. 012012. doi: 10.1088/1742-6596/1171/1/012012

Ramayulis. (2010), Psikologi Agama. Jakarta: Kalam Mulia.

Setiyowati, A. (2017) , Jurnal Masharif Al-Syariah , Analisis Peranan Pengelolaan Dana ZiswafOleh Civil Society Dalam Pemberdayaan Ekonomi Umat (Studi Kasus Lazismu Surabaya)', Vol. 2, No. 1 , 2(1),

Shaleh, Rasyid Akhmad, (1977), Manajemen Dakwah Islam. Jakarta: Bulan Bintang.

Sulistya, I. E., Budirahayu, N. and Ningtyas, R. A. (2020) 'Utilization of Zakat as a Means Empowering People In Indonesia', p. 14.

Undang-Undang Republik Indonesia No. 41 Tahun 2004 Tentang Wakaf.

Wahyuddin, (2006), Manajemen Penghimpunan dan Pemanfaatan Zakat, Infaq, dan Sedekah (ZIS) dan wakaf Uang Melalui Teknologi Informasi pada Lembaga Amil zakat (LAZ) PORTALINFAQ. Skripsi. Jakarta: Fakultas Dakwah dan Komunikasi UIN Syarif Hidayatullah

Zanah, R. F. M. (2016) 'Pengaruh Fungsi Manajemen Terhadap Kepuasan Kerja Karyawan (Suatu Kasus di Home Industri Asri Rahayu di Wilayah Majalengka)', 4, p. 10 